\title{
Behind the Curtains of State Power: Religious Groups and the Struggle for Ascendancy in Nigerian Public Institutions - ACritical Appraisal
}

\author{
Nkolika E. Obianyo*
}

\begin{abstract}
In secular states, religion is expected to occupy a backseat in public life; but in states like Nigeria, this is not so as religion, after ethnicity, has turned out to become a major determinant of political behaviour. It serves as both a unifying and a divisive factor. It unifies Nigerians who share the same belief across ethnic lines and, at the same time, puts them in contest with others who hold different beliefs. Hence, there are several contestations along religious lines. The proliferation of these divides has also given rise to the proliferation of these contestations. Traditionally, this contest has been between the Moslem and Christian groups; but contrary to popular opinion, within the two major religious groups there are several other contestations. Today, there is the contest between Pentecostal and non- Pentecostal Christians, Roman Catholics and non-Roman Catholic Christians (especially the Anglican sect). These contests focus on the relative strength of each group or sect in the corridors of state power. Against this backdrop, this article examines the origin and dynamics of this trend with respect to the Christian religious group in Nigeria. It argues that religion, like ethnicity, serves as instrument for the acquisition of state power, public positions and resources, and consequently as an instrument of exclusion and inclusion in the quest for ascendancy among contestants for state power and public positions. The article argues that this trend cannot be divorced from the 'rentier' and 'allocative' character of the post-colonial state of Nigeria in which occupants of state power not only use the state to improve their material well-being but also that of their primordial groups from which
\end{abstract}

* Department of Political Science, Nnamdi Azikiwe University, Awka, Anambra State, Nigeria. Email: nkolikae@yahoo.com 
they draw support when the competition gets stiff. The ar ticle examines the implications of this trend for development and efficiency of public institutions in Nigeria.

\section{Résumé}

Dans les états laïques, la religion est censée être reléguée au second plan de la vie publique ; mais dans des Etats comme le Nigeria, il n'en n'est pas ainsi, puisque la religion, après l'ethnicité, est devenue un déterminant majeur du comportement politique. Elle sert à la fois de facteur d'unification et de division. Elle unifie les Nigérians qui partagent les mêmes convictions religieuses, quelle que soit leur appartenance ethnique et, en même temps, les oppose à d'autres qui ont des convictions différentes. Ainsi, il y a plusieurs contestations fondées sur la religion. La prolifération de ces dissensions a également entraîné la prolifération de ces contestations. Traditionnellement, cette contestation opposait les groupes musulmans et chrétiens ; mais contrairement à l'opinion populaire, au sein de ces deux grands groupes religieux, il y a plusieurs autres contestations. Aujourd'hui, il y a la contestation entre chrétiens pentecôtistes et nonpentecôtistes, catholiques romains et non-romains (en particulier la secte anglicane). Ces contestations sont axées sur la force relative de chaque groupe ou secte dans les coulisses du pouvoir étatique. Sur cette toile de fond, le présent article examine l'origine et la dynamique de cette tendance, en ce qui concerne le groupe religieux chrétien au Nigeria. L'article soutient que la religion, tout comme l'ethnicité, sert d'instrument pour l'acquisition de pouvoir étatique, de postes publics et de ressources, et par conséquent, d'instrument d'exclusion et d'inclusion dans la quête d'ascendance entre ceux qui se disputent le pouvoir étatique et les postes publics. L'article soutient que cette tendance ne saurait être dissociée du caractère « rentier » et « allocatif » de l'État postcolonial du Nigeria dans lequel les détenteurs du pouvoir étatique non seulement se servent de l’État pour améliorer leur bien-être matériel, mais aussi celui de leurs groupes primordiaux auprès desquels ils obtiennent du soutien lorsque la compétition devient rude. L'article examine les implications de cette tendance pour le développement et l'efficacité des institutions publiques au Nigeria.

\section{Introduction}

The Nigerian public sphere is a highly contested terrain, a contestation that involves several groups struggling for ascendancy and hegemonic control of this sphere in order not only to propagate and perpetuate their interests but have them consolidated and protected against other opposing interests seeking to take control of the power that the control of this sphere offers. This contestation has always showcased ethnic conflicts as the major contestations even when some of these conflicts are tainted with religious colorations. This assumption is predicated on the fact that in Nigeria ethnic cleavages tend to coincide with religious cleavages. Many Northerners are Moslems while majority of the Southerners are Christians. An attack against Christians in the North easily translates into an attack against the Southerners, especially the Igbo ethnic group, which does not subscribe to the Islamic 
religion. Consequently, the influence of religion in the politics of Nigeria tends to be overshadowed by ethnic factors. This is not to say that religious considerations do not play significant role in the nation's power play; in fact at a particular point in the nation's history, politics became so 'religionised' that it divided the citizens into two worlds; the Moslems and the Christians. Thus the debate over the constitutionalisation of Sharia courts, furore made over Nigeria's membership of the Organization of Islamic Countries (OIC), the June 121993 election, the promulgation of Sharia laws by some Northern states in Nigeria, and the threat by the leadership of the Christian community to call on their members to boycott the 2006 national census if religious affiliation was not included in the form, all attest to the occasional ascendancy of religion in the body politics of Nigeria.

The Nigerian ruling class, operating within the context of a secular state, has always tried to downplay the influence of religion in the open arena of political battle; but somehow has also managed to smuggle it in through the back door in its struggle for the control of state power. However, while a lot of attention has been paid to the Christian and Moslem contestations in Nigerian politics, not much attention has been given to a similar trend among diverse denominations of the two religions - for instance, the contest between Roman Catholic Christians and their Protestant rivals, and between the orthodox Christians and their Pentecostal/Evangelical rivals. These contests have gone beyond the struggle for converts and enlargement of membership, to the struggle for the control of state power and other apparatuses of the state. In effect, religion which in the past played a covert role in the contest for state power and other public positions is fast assuming an overt role in this regard. Today churches are more overtly involved in political campaigns and the power play involved in the distribution of public offices. Aspirants to political offices now seek endorsement of the top clergies of the various churches to ensure victory at the polls, governorship aspirants pick running mates from rival Christian denomination(s) to ensure not only balance of the various denominations in the ticket but also in order to assuage voters from the rival denomination(s) as their negative reaction can become a reason for loss of votes at the polls.

In the civil service and parastatals the quest for ascendancy by the various religious groups or denominations is also becoming pronounced. Religious divisions and religious favouritism are fast becoming the norm rather than the exception. Sometimes public offices are turned into mini churches during office hours in a display of piety that arises more from a showmanship of power than love for God; as many subordinates are compelled to attend this 'fellowship' (as these gatherings are called) against their will or in order not to offend their boss(es). 
Against this backdrop, this article examines the emergent overt role of religion in the quest for and consolidation of state power and public positions in Nigerian public institutions. It traces the dynamics of this trend amongst the Christian denominations in the eastern states of Nigeria. It argues that religion, like ethnicity, serves as an instrument for the acquisition of state power and control of public positions and resources in an increasingly 'allocative state' of Nigeria. (Luciani 1987 in Ibrahim 2003:53) In so doing, the article is divided into four sections. Section I deals with conceptual issues surrounding the instrumentalisation of religion for purposes of control of state power. Section II is devoted to a brief history of religion and the struggle for state power in Nigeria. Section III is a critical analysis of the contestation amongst the various Christian denominations in the struggle for state power and public offices against the theoretical backdrop of a rentier state, with special focus on the South East states where the Christian denomination is dominant. Section IV is summary and conclusion.

\section{Religion as Instrument of State Power: Conceptual Issues}

One of the intriguing aspects of Nigerian politics is the ease with which the political class capitalises on any form of identity to capture state power or public office. At one time ethnicity is used; and where the ethnicity is not catching on, religious sentiments are employed. Ethnicity in this sense also includes other forms of local identities that have come to be known in Nigeria as the indigene factor. In other words, the history of Nigerian politics is one in which one form of identity or the other has always played a role. In Nigeria the ethnic consideration has always overtaken other considerations. On the whole, religious consideration has always accompanied or trailed behind ethnicity. However, identity as a construct for the analysis of Nigerian politics has not been the core of intellectual engagement of issues in Nigerian politics, due to what Mustapha (in Jega 2003:12) identified as the phobia amongst a certain category of scholars of African politics not to undertake any intellectual work that may jeopardize the national integration project and also partly as a result of most radical scholars' preoccupation with class determinism as an explanation of African politics.

Although the identity thesis is gaining prominence in the analysis of African politics as argued by Bangura (1994) in Jega (2003:12), it still does not detract from the fact it has always been politicised by the political class for selfish reasons. Identity works because it is anchored in psychological givens and social roles, like emotional tie to a group, as well as obligations and responsibilities relating to membership of a group with which a person identifies (Jega 2003:14-15). It is perhaps this emotional tie which underlies 
identity relations that politicians manipulate in a rather interesting manner to oust opponents in the struggle for public office. In addition, the dynamic and fluid way in which these identities are picked and dropped as situation demands portrays identity as not being the underlying basis of social and political action. In fact Pye (1962) in Jega (2003:15) notes that 'those who share an interest share an identity, thus the interest of each requires the collaboration of all'. It is this shared interest that determines or (in the case of communal groups) enhances identity consciousness. Jega (2003:15) thus notes that the question of which sort of identity has the most significant impact or bearing on a person's behaviour is a critical issue and a subject of intellectual speculation. He argues that while identities are more or less fixed, identity consciousness is dynamic. 'Hence, mobilization, provocation, and agitation are central to the formation of a requisite identity consciousness which in turn is critical to identity based politics'.

In Nigeria the mobilisation and manipulation of identity groups in the quest for political power is a known phenomenon. This manipulation has always succeeded because of the indifference of the state, colonial and post-colonial, to the feelings and welfare of the people (Nnoli 1978; Ake 1996; Jega 2003). Identity politics thrives because many of the identity groups in Nigeria, whether ethnic or religious, have always acted as buffers against excruciating economic hardship of the state. In this vein, Jega (2003:15) notes that in competition or struggles over societal resources, especially in situations of scarcity, collective demands tend to be predicated and organised on shared interests which in turn tend to be hinged on either psychological 'givens' or on shared socio-cultural identities. Hence identity politics becomes 'nothing more than the mutually reinforcing interplay between identities and the pursuit of material benefits within the arena of competitive politics'(Joseph [1987] in Jega 2003:15).

Thus identity politics, whether ethnic or religious or both, thrives in Nigerian politics and tends to emasculate class interests because it is beneficial both to the political ruling class that uses it and the mass base of these identity groups. For the politicians, it provides them with ready political base for ascent into political power positions of their dreams, and on the part of the masses it creates easy access to state power and state resources when a member of the in-group is in charge (Nnoli1978; Ake 1996; Obianyo 2001; Jega 2003). Thus it is not uncommon to find these identity groups organising some form of party or 'welcome reception for a member who has just been elected or appointed into the exalted position of state power with a catalogues of demands of what is expected of him/her as contribution 
to the in-group while in office - a practice that Joseph (1999:67) termed 'prebendalism'. He defined prebendalism as

one in which the offices of the state are allocated and then exploited as benefices by the office holders, but also as one where such a practice is legitimated by a set of political norms according to which the appropriation of such offices is not just an act of individual greed or ambition but concurrently the satisfaction of the short term objectives of a subset of the general population

Sandbroke, in Joseph (1999:68), identified insecurity - physical and material as the major reason individuals seek attachment to 'big men' capable of providing protection and advancement. Thus the use of public office for personal aggrandisement or to sustain private loyalties has led to another debate as to the relationship between the public and the private in Africa, and the nature of the state in Africa.

Writing on this, Chabal and Daloz (1999:1-13) argue that the persistence of pre- colonial norms and values alongside colonial norms and values in the post colonial state shows that the post-colonial state of Africa is a mere shadow of the original - the original being the state in the west. They argue that in the post colonial state of Africa political legitimacy derives from a creatively imprecise interaction between the 'ancestral norms' and the logic of the 'modern' state. The modern state depends, above all, on the gradual emancipation of established political structures from society. It is the outcome of a process by which the realm of politics is gradually emancipated from society and constituted into increasingly autonomous political institutions. The post-colonial state, in their view, has failed to become differentiated from society over which it rules and, therefore, cannot acquire the neutral political status which would allow its legitimation and proper institutionalisation. 'The edifice conforms to the western template, while the workings derive from patrimonial dynamics'. In a way, it is a counterfeit of the western model, meriting the adjectival phrases used in describing it as 'the non-emancipated state' or the 'undifferentiated state'(Chabal \& Daloz 1999:4-8).

This lack of differentiation is what has contributed to the blurring distinction between what is public and what is private in African politics. Thus 'state service is resolutely particularistic and personalized, far removed from bureaucratic norms'. Consequently, 'public employment is exploited as private resource (Chabal and Daloz 1999; Anders 2002). The colonial state was blamed for this non-consolidation of the institutional superlatives of the modern state before independence was granted to the colonies. 
However, Chabal and Daloz failed to identify the specificities of the colonial state that made consolidation impossible. They also failed to recognize the contribution of the colonial state and its ruling class to the articulation of modes of production and corresponding social relations emanating therefrom that characterised the post-colonial state. In other words, the persistence of the pre-colonial modes of production alongside the capitalist mode introduced by the colonial state is attributable to the exploitative and divisive policies and politics of the colonial state (Nnoli 1978; Nnoli 1989; Ake 1996; 0bianyo 2001; Ekeh in Osaghae 2003).

Ekeh (1978:318-319), in Osaghae (2003) provides an excellent explanation on the bifurcation of the public realm in African political life. In his postulations of the two publics in Africa, Ekeh argues that under colonialism, the public realm unlike that of western society developed as two publics rather than one. First, 'an amoral civic public from which one expects benefits but which is not important in one's definition of one's duties' and a moral primordial public, defined in terms of one's ethnic group, to which one's relationship were predominantly phrased in terms of duties'. The primordial public which identifies with primordial groupings, sentiments and activities nevertheless impinges on public interest to the extent the groupings, ties and sentiments influence and determine the individual's public behaviour. This public owed its existence to the alienating nature of the colonial state and its failure to provide the basic welfare and development needs of the masses of ordinary peoples. This public provided social welfare services and public goods like credit facilities, scholarship, health care centres and the like, which the state failed to provide its citizen subject (Osaghae 2003) Two significant elements of this public are:

(i) The strong sense of ownership by members of its constituents who fiercely resist state intrusions other than those that are of immediate benefit;

(ii) The primordial public is moral and operates on the same moral imperatives as the private realm. In this public, social exchanges are based on mutual reciprocity between rights and duties part of which is a moral responsibility on the part of individuals in positions of influence to ensure the collective and individual well-being of members of the group (Osaghae 2003).

In contradistinction to the primordial public is the civic public which is historically associated with the colonial administration and which has become identified with popular politics manifested in Africa. Though the civic public 
may not be coterminous with the state, it is, no doubt, associated with the various public apparatuses of the colonial state like the police, the civil service etc. It is characterised by two features:

(i) It suffers from endemic crisis of ownership; the people do not claim or identify with it as they do with the primordial public. It is marked by the 'us' versus 'they' relationship where the 'us' is the primordial public whose ownership, autonomy and sustenance are jealously guarded;

(ii) The civic public is amoral and lacks the generalised moral imperatives operative in the private realm and in the primordial public. Thus, the individual feels no moral urge to reciprocate the benefits he receives from it and the behaviour that would be regarded as morally reprehensible in the primordial public, such as embezzlement of public funds is permissible here in so far as the larger group directly or indirectly benefits from the loot (Osaghae 2003).

The contradictory pulls and demands of simultaneous membership of the two publics is what underlie the pervasive problems of ethnicity, religious politics and state corruption that it engenders (Osaghae 2003). Osaghae further contends that if the post-colonial state civic public suffers the fate of the colonial state, it implies that it has the sane attributes as the colonial state.

What can easily be discerned from the theory of the two publics is that the post-colonial state has continued to be an object of plunder and abuse by those who should protect it because of the lack of any form of affinity or tie between it and the local populace, including the emergent local bourgeois class that inherited the state. What is not clear from Ekeh's analysis is whether it is the amoral character of the colonial state that resulted into this lack of affinity or the fact that the contributions of the local people were trivialised by the colonial state, thus creating the impression that the newly created state was only a dispenser of favours and that duties and obligations of the citizens were not important. Without trying to regurgitate what is already a familiar argument in social science circles, the post-colonial state inherited all the attributes of its progenitor - the colonial state. However, one important attribute of this state is its leviathan role in social and economic spheres and its rentier character. The use of the state apparatus for rent collection started with the colonial state. This trend continued with the post-colonial state not just because of the weak economic base of the political class that inherited it but also as a result of the lack of bonding or feeling of ownership between the civic public as represented by the state and its apparatuses and the local bourgeois class that took over after independence. The post-colonial state became more statist and allocative, given the ideological imperative that 
propelled it to power - the ideology of welfarism and development. In the bid for a more secure material base, coupled with the high hopes for a better life promised to the people at independence, the state assumed a larger than life role in the economy. All the 'commanding heights' of the economy were under the control of the state. This phenomenon raised the stakes attached to state power. The post-colonial state became the major dispenser of rewards and benefits in the society. Thus material security became synonymous with state power. This intensified the struggle for state power and its control. In addition, the huge rent accruing from oil revenue in Nigeria became additional impetus for the warfare that characterised the struggle for state power. As Ake (1996:7) puts it:

The winners in the competition for power win everything, the losers lose everything. Nothing can be more than losing, nothing, better than winning. Thus everyone seeks power by every means, legal or other wise and those who already control state power try to keep it by every means. What emerges from this is a politics which does not know legitimacy or legality, only expediency...

Reiterating on the absence of public space he notes:

Our politics is not a lawful competition to select those to manage our common concerns but a fight to capture and privatize an enormous power resource. There is no public realm, strictly speaking, no state. There is only a contested terrain, where interest groups and communities go to fight for appropriation.

The point we are making is that the rentier character of the state is partly responsible for the plunder of the state and the instrumentality of identity whether of ethnicity or religion in the struggle for state power. A rentier state and rentier economy is the product of a post-colonial state with very weak productive base and externally-controlled economy dependent on revenue from sale of primary commodities for survival. It is also characterised by a dependent ruling class with weak economic base who also depend on external rent accruing to the state for private accumulation. Thus a rentier economy relies substantially on external rent and the government is the main recipient of this rent. One of its major features is that production efficiency is relegated to the background and, there is at best a tenuous link between individual income and activity and getting access to the rent circuit is greater preoccupation than attaining production efficiency (Beblawi \& Luciani 1987 in Ibrahim 2003:53).

The importance of access in a rentier economy leads to a rentier mentality, which embodies a break in the work - reward causation'. Reward - income 
or wealth is not related to work and risk bearing, rather to chance or situation. For a rentier, a reward becomes a windfall gain, an isolated fact, situational or accidental as against the conventional outlook where reward is integrated into a process of the end result of a long, systematic and organized production circuit (Beblawi 1987 in Ibrahim 2003:53).

This has resulted to a glaring contradiction between rentier and production ethics. The rentier state is oriented away from the conventional role of providing public goods that have been extracted from the people through taxation to become a provider of private favours. Consequently, it has become what Luciani (1987) in Ibrahim (2003:53) termed an allocation (as distinct from a production) state. A rentier state is anchored on the privatisation of the public sphere made easier and acceptable by the persistence of the primordial production relations based on kinship and communal ties. In addition, the post-colonial state is limited by its lack of autonomy from the emergent factionalised ruling class that pilots its affairs. Immersed as it is in intra-class conflict, its enormous wealth base became an instrument of legitimation for any faction that controlled it. This legitimation was sought primarily from the various primordial and/or identity groups that provided the mass support for the various ethnicised factions of the ruling class. This further consolidated the instrumentality of identity or ethnic groups in the contest for state power. Paradoxically, identity formation and consciousness in the colonial state was not limited to ethnic and other cultural affinities, but rather new identities resulting from the web of colonial activities gave birth to new forms of identities. These include identity groups formed around Christian religious sects and educational institutions. Thus, the sense of community exhibited by the different adherents of the new Christian religious groups, especially in engaging opponents of other faiths, led to a proliferation of identity groups of diverse and cross-cutting interests. It is also not uncom-mon to find Christian religious groups, or even products of their educational institutions, forming groups along communal lines in the cities and towns.

Writing about Malawi, Anders (2002) notes that ' $\ldots$ in an urban and modern environment other networks based on residence, social status and church membership is very important'. Thus, urbanised and 'modern' civil servants maintain diverse social relationships with neighbours, colleagues, old schoolmates and fellow members of the church congregation. In fact, primordial ties also characterised the emergent civic publics that developed from the colonial state. The neo-capitalist system ran by the colonial state, embedded as it were in alienatory and exploitative policies, neither allowed for the disappearance of the communal production relations nor atomisation of society that inheres from capitalist production system. The communal 
production relations penetrated and harmonised with the post-colonial 'modern' state based on capitalist production relations in a rather peculiar way that has rendered the state dysfunctional to public concerns. Chabal and Daloz (1999:16) thus conclude that in most African countries, the state is no more than a décor, a pseudo-western façade masking the realities of deeply personalised political relations.

It is within the purview of the rentier state thesis that we can begin to discern the instrumentality of religion in the struggle for state power in Nigeria.

\section{Religion and Politics of State Power in Nigeria: Historical Antecedents}

The state in Nigeria has been in both complementary and dialectical relationship with religious groups in Nigeria. It has been a relationship of harmony and conflict. Suffice it to state that the modern state in Nigeria has been a partner of Christian religious groups that not only preceded it but complemented its role of 'civilising mission' in Africa. The British trading companies, the Christian missions and the colonial state all penetrated Nigeria at about the same time. According to Coleman (1986:41), as early as 1826 twelve British companies were already in the Bonny River. The discovery in 1830 that the Niger entered the Bight of Biafra served as an invitation for many traders to penetrate the hinterlands. At about the same time (1846), the first Christian missionary of the Presbyterian denomination arrived from Scotland to the Duke Town of Old Calabar. By 1875, another mission known as the Christian Missionary Society (CMS) of the Anglican Church arrived in Onitsha. This was followed by the Roman Catholic Mission (RCM) arrival at Onitsha in 1885 (Amucheazi 1986:11-12). After the Berlin Conference of 1885, Britain gave the Royal Niger Company power to 'administer, make treatises, levy customs and trade in all territories in the basin of the Niger and its effluents'(Coleman 1986:41) This power gave the company monopoly control of trade in the region.

By 1900, the British Government took over control from the Royal Niger Company. Lord Lugard was appointed the High Commissioner of the Protectorate of Northern Nigeria. The year 1904 saw to the amalgamation of the Southern Protectorate with the Lagos Colony, while in 1906, the Protectorate and Colony of Southern Nigeria was merged with the Northern Protectorate giving birth to the Colony and Protectorate of Nigeria (Coleman 1986:41-42). Thus commerce, Christian Missions and the colonial apparatuses appeared on the Nigerian scene at about the same time and also maintained a close tie. For instance, the missionaries sought the help of the colonial state in destroying shrines and supposed 'fetish idolatry worship' 
of the native population, while they at the same time engaged in training of local personnel through missionary education for administration of the state, at a time when the colonial state was in acute shortage of staff (Amucheazi 1986:21; Obianyo 2001).

As Amucheazi (1986:17) observed, the triumvirate alliance was of fundamental importance to the success of Christian missions in Eastern Nigeria. The instrumentality of the Christian Missions in the consolidation of colonial values and colonial rule in Nigeria lay in their involvement in the provision of vital public goods which the state should have undertaken, namely, education, health services and other social services. Although their involvement in these services were for evangelical purposes and the quest for membership, it nevertheless fulfilled a real economic function for both the natives seeking enhancement in their material position in the changing political economic and social situation, as well as for the colonial state which felt relieved of a burden that would have eaten into its already lean purse for administration.

Amucheazi also observed that through the provision of these services, the missions were able to raise funds, and win more converts which also translated into more funds for the church. The material relevance of these services was to account for the bitter struggle between the CMS and the Roman Catholic Mission on the one hand and the state and the Roman Catholic Mission on the other (Amucheazi 1986:23). Obviously because of the CMS higher education policy, it was able to produce highly skilled manpower that were later to dominate the emerging state apparatuses; thus attacks on state policies of quasi-independent regions translated into attacks between adherents of the two denominations. For instance, when the NCNCled government in Eastern region embarked on a comprehensive education policy which was aimed at producing useful self-confident and competent citizens, with loyalty to the state, but which was likely to take away education from the control of the missions, the Roman Catholic Mission not only criticised and decried the policy but also used abusive language against its authors who were mainly of the Protestant order. The Protestants saw this as an attack on its members. The RCM even went as far employing overt political action of calling on its adherents to shun nationalist movements. It also fielded candidates for election against all candidates of non-Roman Catholic faith nominated by the NCNC. (Amucheazi 1986:85-87).

In the ensuing quest for hegemony in the dictation of policy objectives of the state, and in the bid to engage politics to protect their interests, the rival churches embarked on the formation of special laity councils, namely the Eastern Nigeria Catholic Council (ENCC) and the Convention of Protestant Citizens (CPC).The later was a response to the aggressive political 
activities of the former. The two bodies were to socialise the laity for political participation on behalf of the church (Amucheazi 1986:104-109). In our conceptual discussion, we noted that the civic realm also operated social relations based on primordial ties. Thus in their structural arrangement, the church persistently followed the boundary mapping of the state. Sometimes priests were sent to their local communities for pastoral work. The aim was to create an identity of interests between the minister and the community.

Amucheazi (1986:81) notes that indigenisation of denominational staff received active encouragement from all the churches. Thus when the Anglican Diocese of Aba was created after the war and Rt. Rev. Afonya from Rivers state was appointed its Bishop, it was resented by the indigenes of the Diocese. This goes to show the extent primordial ties infiltrated other civic groups. The position of a bishop is a highly rewarding venture materially that many communal groups jostle for as they do other positions of power. These conflicts laid the foundation for the clash of interests between members of these denominations in the post-colonial state.

In the northern part of the country, the state engaged religion and religious groups in a different way. First, the colonial state debarred the Christian Missions from evangelising the Moslem-dominated north. This decision was attributed to the need to keep intact the rich culture and administrative structure which the colonial state met in the North and which facilitated colonial state administrative policy of indirect rule. This policy was to have its own negative implications in the integration of the northern and southern parts of the country. While the South became advanced in western education - the gateway into the colonial state apparatuses - the North lagged far behind as the state engaged in literacy programme very late. The disparity in culture and values generated by this was later to induce the feeling of suspicion and fear of domination between adherents of the two dominant religions. Thus in a situation where ethnic and religious boundaries coincide, one conflict easily translates into another. Thus fear of Northern domination of state power was at the same time fear of Moslem domination over Christians and vice versa. This was to play out in the quest for control of state power/public offices and distribution of patronage and resources. A representative view was that of Alhaji Isa Kaita (in Kukah 2003:6):

When politics came, in view of what was happening in the whole country, we did not have the choice, we were all conscripted into politics to fight for the North and to defend her interests against southern domination.

Kukah (2003) also observed that religion being the basis of the foundation of the caliphate, its importance in political competition remains unrivalled. The realisation of its potency led the ruling elite to cast political opponents 
in religious terms. For instance, when Northern Elements Progressive Union (NEPU) went into alliance with the NCNC, a southern party, they were projected as a people who had sold out on their religion. The 1966 Nzeogwuled coup in which many Northern politicians were killed, triggered a crises that was as political as it was religious. The result was the reprisal attacks against the Igbos in the North and the ensuing three-year civil war.

Nigeria was to witness another politics of religion during the (in)famous Sharia controversy of 1977-8 Constituent Assembly debate. The core of the controversy revolved around the inclusion of the constitutional provisions for the establishment of a Federal Sharia Court of Appeal to deal with cases brought before it by Muslims. The underlying reasons for this demand is that the Muslims believe that the common law used in Nigeria is essentially Christian and even the spirit of the constitution is Christian in orientation. The Muslims have to struggle to get a well deserved position in the constitution (Mu'azzam \& Ibrahim 2003:71). A representative view was that of Dr. M.T.A. Liman who advised that 'a Muslim vigilante group should be formed at the national level to alert the nation whenever they feel that Islamic interest in any place, at any level is being violated or sacrificed' (Liman 1977 in Mu’azzam \& Ibrahim 2003).

For the Christians, introducing Sharia or a Federal Sharia Court of Appeal amounts to giving undue preference to Muslims in a state and constitution which is secular. Rev Wilson S. Saboya (1979 in Mu'azzam \& Ibrahim 2003) thus asserts that 'to entrench Sharia in the constitution is to legalise the inferiority of non Muslims and the superiority of Muslims...' Other strong opposition came from Paul Unongo, a foremost Nigerian politician from the Middle Belt region and a member of the Constitutional Drafting Committee (CDC) He argues that, ' ... There is no basis at all to even discuss the probability of providing a court structure or system which by definition is a religious court and use federal funds to maintain such a religious court in a secular state...' Sharia system, in his view, runs counter to the political objectives and social order on which we seek to build a nation. The Constituent Assembly resolved the matter not by submitting to the desires of the Sharia court protagonists but by finding a middle ground solution in which it was resolved that cases of Sharia on Appeal shall be heard by a Federal Court of Appeal in which three judges learned in Islamic law shall constitute the court (Kukah 2003:125). A similar argument dotted the nation's political landscape during the Babangida government's constituted Constituent Assembly of 1987-88 (Mu’azzam \& Ibrahim 2003).

The Sharia controversy reared its ugly head once more when Nigeria returned to civilian rule in 1999. Some political leaders in the north tried to secure political legitimacy and hero status by advocating for Sharia state. 
This group of political leaders hailed from states led by Zamfara State. The attempt by Kaduna State to follow the Zamfara example led to a serious riot which claimed casualties on both sides. The Sharia controversy of the Fourth Republic was believed to be a reaction to the Christian-led government of Rtd Gen. Obasanjo (who announced himself as a 'born again' Christian on assumption of office), and perceived political marginalisation of some Northern Muslim politicians. The whole essence was to undermine the Obasanjo administration and make the country fragile and ungovernable for him. It was also used as a platform to bring together once more an already factionalised northern political class. Thus with the Sharia crisis of the Fourth Republic, religion superseded ethnicity as the major driving force of political legitimacy (Korieh 2005). It also suggests, among other things, the increased use of religion by stakeholders to push political agendas.

Another heated religious issue in Nigeria's national politics revolved around Nigerian membership of the Organisation of Islamic Conference (OIC) in 1986. The Christians perceived this as a move by the Muslims to turn the country into an Islamic state. The Babangida-led government justified the membership on the grounds that it was a forum for co-operation in economic, technical and cultural matters. The Christian Association of Nigeria (CAN) responded with series of wake-up calls and publications aimed at raising the consciousness of the Christians to make them more active in the struggle for hegemonic control of state power in Nigeria. CAN, for instance, published a book titled 'Leadership in Nigeria' in which it tabulated the Christian/Muslim ratio in the powerful decision-making positions of the Nigerian state. Though the publication centred on the Babangida regime, the facts contained therein favoured the Christian group as being dominant in the decision-making positions of the state -204 Christians as against 138 Muslims who have participated in the Armed forces Ruling Council(AFRC), Council of Ministers, as wells as Council of States (Bari 1990 in Mu'azzam \& Ibrahim 2003:73) The retirement of some prominent Christian minority elements from the[Middle Belt] North like Gen, Domkat Bali also spawned controversy, leading to inciting publications by CAN. The problem was compounded by the botched Orkar-led coup of April 22, 1990 in which some Northern Muslim-dominated states were excised from Nigeria (Mu’azzam \& Ibrahim 2003). Inciting political statements tending to exploit religious sentiments did not help matters. Chief Arthur Nzeribe was quoted to have said in an interview with a Christian newspaper, The Leader that, 'Christianity and Islam will be the underlying factors in the 1990 elections...time has come for the Christians to be political...' Some Muslims expressed similar feelings. A representative view was that of Fakki, 'It is incompatible with Islam, therefore to pledge support to any political party 
of a non Islamic platform or to yield to a non-Islamic government of alien origin and aims...' (Mu'azzam \& Ibrahim 2003:75).

These statements were made against the background of the two-party systems of the Babangida transition politics which nullified ethnicity as a platform for political campaigns. In a similar vein, the presidential aspirant of the All Nigerian Peoples Party (ANPP) was alleged to have made statements inciting Moslems not to vote for a Christian candidate in the 2003 election. Though he debunked the allegation, it however earned him the dislike of many southern Christians. Apart from these overt religious controversies spanning the nation's political landscape, there have always been covert attempts by the ruling class to ameliorate the fear of religious domination by balancing the various political positions with members of the two dominant religions. At all times, the chief executive and his/her deputy has always been drawn from the two religious groups - Islam and Christianity.

In the first republic, the President in the person of Chief Hon. Dr. Nnamdi Azikiwe was a Christian while the Prime Minister, Alhaji Tafawa Balewa, was a Muslim. The Ironsi administration that succeeded it had Babafemi Ogundipe as Vice, while the Gowon administration was a balancing of ethnicity than religion. But military consideration held sway. Being a Christian from the North, his deputy was first, Joe R.I. Akahan, followed by Iliya B. Bisalla, Hassan Usman Katsina, David Akpode Ejoor, and then J.E.A.Wey. The administration that toppled him was led by the late Gen. Murtala Mohammed, a Muslim, but his deputy Rtd Gen. Olusegun Obasanjo, was a Christian from the South West. When Mohammed was murdered in the failed coup of 1975, Obasanjo took over power but his deputy was a Muslim northerner, the late Gen. Shehu Musa Yar'Adua. The civilian administration of Alhaji Shehu Shagari, a Muslim, which followed had Chief Alex Ekwueme, a Christian, as his Vice. The Gen. Buhari administration that ousted the Shagari regime did not think much about the balancing of religion in the most powerful positions of the state as his deputy, the late Major Gen. Tunde Idiagbon, was also a Muslim. The administration's primary aim of fighting corruption/indiscipline in the system did not leave much room for politicking, as many members of the political class at that period populated the prisons in Nigeria over allegations of self-enrichment through corruption. Babangida, who succeeded Buhari, had as deputy Air Commader Ebitu Ukiwe, a Christian, who was later replaced by another Christian, Admiral Augutus Aikhomu. When Babangida stepped aside after the imbroglio surrounding the cancellation of the June 12 election in which a Southern Muslim was said to have won, the interim administration that succeeded him was led by a Christian, Chief Ernest Shonekan, assisted by the late Gen Abacha, a Muslim who later ousted him in a palace coup to take over the 
reins of government. Gen. Abacha was assisted by Major Gen. Oladipo Diya, a Christian from the South West. Following disagreements between the two, Diya was replaced by Gen. Jeremiah Useni, another Chritian from the Middle Belt. The transition government of Gen. Abdusalami was assisted by Michael Akhigbe, a Christian. Under the regime of Obasanjo, his Vice was Alhaji Atiku Abubakar, a Muslim from the North, Under the regime of Alhaji Umaru Musa Yar'Adua the Vice President was a Christian from the minority South-South geo-political zone, Dr Jonathan Ebele Goodluck. Much as the ethnic consideration held sway in these appointments, it nevertheless balanced up the religious divisions as the ethnic and religious divides in Nigeria tend to coincide.

\section{Christian Religious Groups and the Contest for State Power/ Public Offices in the South East of Nigeria: A critical Analysis}

Amucheazi (1986) observes the effort made by the various Christian denominations in the Eastern region, especially the CMS and the RCM, to structure their organisations along lines of political boundaries - provincial or divisional. The practice, he argues, seemed to have been to group together wherever possible people of the same or near common affinity within one Diocese. This practice has not ceased today. The implication of this exercise is that in politically homogenous communities, the religious divide plays greater role in the choice of candidates for election than ethnic or communal consideration. Hence since the creation of states in 1991 that brought into existence Enugu and Anambra states, ethnicity or the indigene factor ceased to be a serious platform in the contest for public office. In the absence of the hegemonic politics of powerful interest groups, like businessmen/contractors, religion has become the next powerful political factor in the contest for political and public offices in the various states, particularly Anambra. It is a known fact that the hardship occasioned by the structural adjustment policy and the peasantisation and proletarianisation of the middle class led to the explosion of Christian religious groups known as Pentecostal churches. These emergent groups offered not only spiritual alleviation of the people's suffering but material well-being as well. They promised their congregation faith, wealth and healing, which won them the label of 'prosperity churches' by the orthodox denominations. They also challenged the orthodoxy of the traditional denominations of the Roman Catholic and Anglican order. Professing themselves to be 'born again' in keeping with the admonition of Christ to His followers that only those reborn in spirit shall inherit the kingdom of God, they attracted large followers that frightened the orthodox denominations to allow similar worship style and groups to emerge within their fold. The emergence of Gen. Obasanjo, a 
self-confessed born again, as president energised the Pentecostal belief of redemption and miraculous uplift of God's children. A collaborative view is that of Ibeanu (2006:17):

...in Nigeria today Christianity, especially Pentecostalism, constitutes a distinct social force with pertinent effects.... Pentecostalism, especially under President Obasanjo, is inserted into the political conjuncture in such a way that it brings to it a substantively qualitative difference. The growing members of Pentecostal government officials, the reputation of President Obasanjo as Pentecostal, and liberal infusion of Pentecostal Christian rituals into state functions all point to the existence of Pentecostalism as a social force in Nigeria today.

In Anambra State, a Pentecostal Anglican became the governor of the state in 1999. Governor Mbadinuju promoted Pentecostalism as official government policy, as every Monday morning was carved out for praise worship reminiscent of the Pentecostal order. All civil servants in the state bureaucracy were expected to be in attendance, while the Anambra Broadcasting Service (ABS) broadcast the service for those in other parts of the state who could not attend physically. Sometimes the worship was organized at the Onitsha main market putting business transactions on hold until the exercise was over. Because the people clamoured for material and spiritual redemption from God, the exercise was welcomed until the obvious misadministration of the state leading to infrastructural decay, non-payment of workers' salaries, state orchestrated political violence, all of which portrayed the governor in a negative light. During the 2003 electoral campaigns, religion once again came to the fore as the Roman Catholic Church openly endorsed the All Progressive Grand Alliance (APGA) gubernatorial candidate, Mr Peter Obi, as the candidate of the church. Obi was the favourite of the Catholic Church not only because of his strong catholic affiliation as a member, and with a brother as a reverend father in the Catholic church, but he was in a party perceived by the Igbo as representing the Igbo interest. At this time the people were not only disenchanted with the PDP government in the state but also with the PDP federal government led by President Obasanjo, who was believed by the Igbo to have been on a mission to destroy the material wellbeing of the Igbo.

At the inception of his administration, President Obasanjo embarked on a policy of banning the importation of several foreign goods, foremost of which were used cars above 8 years. The Igbo, many of whom are merchant traders saw this as a deliberate policy to deny them material progress. This led to the resurgence of the Biafra consciousness. Suffice it to add that many of these traders and artisans formed the core of the Movement for the 
Actualisation of Biafra (MASSOB). MASSOB also attracted radical priests of the Roman Catholic Church, as the church became one of the media for communicating to the people about the agenda of the organization. For instance, the sit-at-home order to all the Igbo of South East Nigeria was announced during church service in many of the Catholic churches east of the Niger (Obianyo 2008). Thus the APGA candidate, Mr. Peter Obi, became the favourite of not only the Roman Catholics but also lovers of Biafra who saw APGA headed by the erstwhile Biafran leader, Chief Odumegwu Ojukwu, as another opportunity for the Igbo to reclaim their political birthright in Nigeria. In addition, following the bitter politics between Governor Mbadinuju and his estranged godfather, Chief Emeka Offor, Anambarians became disenchanted with candidates sponsored by political godfathers who ended up emptying the coffers of the state in their bid to reclaim their election expenses.

There were other candidates who sought the blessings of the various religious leaders in the state, like Dr Chris Ngige, but never received the endorsement of any major denomination. Dr Ngige is a Roman Catholic adherent, who campaigned on a subject close to the heart of the Catholic Church - that is return of schools to the missions or churches, yet the church never endorsed him. At the end of the 2003 election, Dr Ngige was declared the winner in a widely contested result. It is important to point out that all the gubernatorial candidates had their ticket balanced religiously. $\mathrm{Mr}$ Peter Obi had as his running mate, Mrs Virgy Etiaba, whom it was alleged was the candidate of the Anglican Archbishop of the Ecclesiastical Province of the Niger. Dr Chris Ngige had as his running mate, Dr Okey Ude, an Anglican but a relation of his political godfather, Chief Chris Uba. Dr. Chris Ngige was later ousted as governor of Anambra state after the Appeal Court judgment that restored Mr Peter Obi as the winner of the election on 15 March 2006. During the administration of both Dr. Ngige and Mr Peter Obi, religious considerations were widely believed to have influenced the various appointments in the state. In keeping with his policy to return school to the mission, Dr. Ngige appointed a Roman Catholic Knight as commissioner of education in the person of Prof L.N. Muoghalu. There have been wide allegations that Govenor Peter Obi favours the adherents of Roman Catholic religion in his various appointments. This belief may be as a result of the dominant position of adherents of the Roman Catholic religion in the state executive council of the governor. For instance, out of 13 cabinet positions, 9 are occupied by Roman Catholic adherents, in addition to the position of the Secretary to the State Government, and Principal Secretary to the Governor, and about five out of a total of seven special advisers. 
In Enugu State, the ex-governor, Dr Chimaroke Nnamani, faced unrelenting attacks from a charismatic Catholic priest, Rev. Father Mbaka. Rev. Mbaka accused the governor of all kinds of crime and misdemeanour, including attempt at his life (Dawodu:2002) These attacks occurred during his weekly prayer meetings at adoration ground (as his prayer ground was called) at Enugu in which many Roman Catholic faithfuls were in attendance. Dr ChimarokeNnamani, an Anglican, found solace in the comfort and support extended to him by his own Bishop and congregation. He also tried to counter the Catholic misgivings about him by endorsing a Catholic as his successor to the high office of governor, although other political considerations also held sway in his choice of the candidate. During the 2007 election, Catholic churches openly influenced their congregation's electoral choice by reading out to them in preferential order, candidates they could support for the gubernatorial election. All the names read out were of Roman Catholic adherents.

Religious affiliation was also employed by other contestants of public office, whether federal or state. In Nnamdi Azikiwe University, a federal university in the South East, at a time religion polarised the university between 1999 and 2003, the incumbent Vice Chancellor was a Roman Catholic. But each time he fell out with the academic Staff over their salary and welfare package, the opposing denomination(s) were accused as masterminders of the effort to undermine his administration. Even when the leadership of the Academic Staff Union of Universities (ASUU) in the University was dominated by Roman Catholics, he accused them of allowing themselves to be manipulated by members of the other major denominations, notably the Anglican Church.

Paradoxically, in the contest of state power, the Roman Catholics always find themselves in opposition to the other denominations, which have a lot in common, in contrast to the Roman Catholic Church. The matter degenerated when the new Vice Chancellor was not a Catholic faithful endorsed by the outgoing Vice Chancellor. The outgoing Vice Chancellor refused to handover to the new one. It was alleged that pressure was mounted on the then Minister of Education, a Catholic, to deny the appointee a letter of appointment and have a Catholic replace him. When eventually the effort failed and the appointment of the new Vice Chancellor was confirmed, the university experienced a lot of politicking based on religion. Appointments to key positions in the university were scrutinised to know which religious group benefited most. Matters came to a climax when the Vice Chancellor had to publish all the academic and administrative appointments in the university and the religious affiliation of the occupants to allay the fears of marginalization by the various religious communities (Unizik Comet 2003). 
Pulpits were regularly employed by some Catholic priests to criticise the administrative policies of the university, just because the incumbent was not a member of their fold. Just recently, an attempt by the Vice Chancellor to hand over to one of his deputy Vice Chancellors, after completing his five years tenure, was engulfed in religious controversy, as it was alleged that the Minister of Education who is a Pentecostal favoured a hand- over to a Pentecostal in an acting capacity pending the inauguration of a new University Council that would oversee the appointment of a new Vice Chancellor. Though the outgoing Vice Chancellor eventually handed over to one of his deputies, who incidentally was a Catholic, this did not go down well with the Protestant and Pentecostal communities in the University.

One may reason that the struggle for hegemony amongst the various religious denominations in publicly-sponsored University would have diminished in the face of the proliferation of private University established by the various Christian denominations. But that has not happened. Just like other public offices with enormous resource base and power, the post of Vice Chancellor carries immense material benefits and patronage powers. An occupant of such position can develop a large network of clientele through provision of employment, contracts, admissions, promotions and donations to causes. More importantly, those who can establish other forms of affinity with him - religious or ethnic - are assured of quicker access to the occupant of such a position and the likelihood of having their request granted. Such occupant is also expected to make huge donations to the group's projects from public funds under his control. This underscores our earlier position as to why the use of religion, just like ethnicity, works as an instrument of exclusion in the contest for state power and other public positions in Nigeria.

\section{Conclusion and Recommendation}

Ibeanu (2006) pointed out the age-old relationship between religion and state politics tracing it back to the era of divine right of kings in Europe .He also remarked on the enviable role played by many Christian movements in championing democratic rights in Europe. In other words, the Church has always intervened in state politics. In fact in Britain, the Queen is the head of the Anglican Communion. In the USA, the Republican Party or GOP's political ideology centres on certain Christian traditional values which have immense implications for the kind of policies pursued by the party while in power. Writings of scholars like Max Weber have also pinpointed the important role of the Christian religion to the emergence of a secular world and liberalism generally. It is not surprising, therefore, that the growth and spread of Pentecostalism of the American type in Nigeria coincided with the adoption of 
the market economy in Nigeria (Ibeanu 2006). Christianity has played strong and overt role in the political process in many advanced democracies.

However, in Nigeria religion has been more of a divisive than a developmental instrument. One recurring decimal in the history and dynamics of religious conflict in Nigeria, whether inter or intra, is that it borders on the accumulation of rewards and benefits which the offices bestow on the occupants and their supporters. The controversies never centre on the production of resources. We attributed this trend to the character of the state as a dispenser of benefits and rewards. State failure occasioned by long years of abuse of public offices and constriction of the political space which make it more difficult for many members of the ruling class to be accommodated in office at any given time, intensifies the struggle for these positions. Every arsenal is employed to oust opponents, namely, ethnicity, being indigenous to an area, religion or whatever else works. Jega (2003:27) explained it this way:

Under conditions of economic crisis, and subsequently structural adjustment, there has been a swift decline in the ability of the Nigerian state to provide for the basic socio-economic needs of the people. Similarly, there has been increased exclusion of a segment of the elite and the bourgeoisie in the distribution of the spoils of office, and an acute marginalisation of the majority of the population from the benefits of development projects and social provisioning. All these have led to an increased crisis of legitimacy of the state.... As the state experiences .... a process of decomposition and recomposition... and disengages from critical social provisioning, only the constituencies and clients of those who control state power actually continue to have access to state resources and patronage. Thus under these conditions groups have tended to rely on identity based politics to struggle for access to the state and the resources that it controls ,in order to protest exclusion and oppression as well as to demand basic rights and socio economic provisioning

Our contention in this article is not that religion and state power should be kept separate or that the Church cannot intervene in the political process positively, but rather that the use of religion to sentimentalize and consequently exclude others from the political process or any competitive position is inflammatory and divisive and does not help developing states like Nigeria to recruit the best human resources they have into public positions. In addition, experiences have shown that those who employ the instrumentality of identity, whether ethnicity or religion, in Nigerian politics do so for selfish reasons bordering on accumulation and not to serve public interest. The pertinent question then is how do we insulate the state or positions of public trust from plunder by the ruling class? 
The solution lies in reorienting the state away from its distributive character and towards production. There is also the need to reduce the material rewards accruing to occupants of public offices in Nigeria, and discourage the use of public offices for private favours and personal purposes. Breach of regulations in that direction should be severely punished as a deterrent. However, this can only be realised if we have purposeful committed leadership ready to lead by example and committed to the progress and development of the people.

\section{References}

Ake, C., 1981, Political Economy of Africa, Nigeria: Longman.

Ake, C.,1996, Is Africa Democratizing? CASS Monograph No.5, Nigeria, Centre for Advanced Social Science.

Ake, C., 2001, Democracy and Development in Africa, Ibadan: Spectrum Books. Amucheazi, E., 1986, Church and Politics in Eastern Nigeria: 1945-1966, Nigeria: Macmillan.

Anders, G., 2002, 'Like Chameleons - Civil Servants and Corruption in Malawi’, Discussion Paper, prepared for the Conference on 'The Governance of Daily Life in Africa: Public and Collective Services and their Users', University of Leiden, 22-25.May.

Chabal, P. and Daloz, J., 1999, Africa Works: Disorder as Political Instrument, Oxford; The International African Institute \& James Currey.

Coleman J.S., 1986, Nigeria, Background to Nationalism, Benin City: Brouburg \& Wistrom.

Dawodu, S.T., 2002, 'Enugu Debacle: Politics in the Name of God - Catholicism and Theocracy’ (http://www.nigerianworld.com/letetters/2002/mar/192.html), 15 September 2002.

Ekeh, P., 1978, 'Colonialism and the development of Citizenship in Africa: A Study in Ideologies of Legitimation' in O, Otite, ed. Themes in African Social and Political Thought, Enugu: Fourth Dimensions

Ibeanu, O., 2006, 'The Church and Democratic Governance in Nigeria: An Explanatory Analysis', Paper presented at the Valedictory Conference in honour of Professor Elo Amucheazi at the University of Nigeria, Enugu, 7 September 2008.

Ibrahim, J., 2003, 'The Transformation of Ethno- Regional Identities in Nigeria', in Jega, A. ed., Identity Formation and Identity Politics Under Structural Adjustment in Nigeria, Kano/Uppsala: The Centre for Research and Documentation and Nordiska Africainstitutet.

Jega, A., 2003, 'General Introduction.Identity Transformation and the Politics of Identity Transformation under Crisis and Adjustment', in A. Jega, ed., Identity Formation and Identity Politics Under Structural Adjustment In Nigeria, Kano/Uppsala, Centre for Research and Documentation and Nordiska Africainstitutet.. 
Jega, A., 2003, 'The State and Identity Transformation under Structural Adjustment in Nigeria', in A. Jega, ed., Identity Formation and Identity Politics Under Structural Adjustment in Nigeria, Kano/Uppsala: Centre for Research and Documentation.and Nordiska Africainstitutet.

Joseph, R., 1991, Democracy and Prebendal Politics in Nigeria:The Rise and Fall of the Second Republic, Ibadan: Spectrum Books.

Korieh, J., 2005, 'Islam and Politics in Nigeria: Historical Perspectives', in J. Korieh and G. Nwokeji, ed., Religion, History and Politics in Nigeria:Essays in Honour of Ogbuu Kalu, University Press of America.

Kukah, M.H., 2003, Religion, Politics and Power in Northern Nigeri, Ibadan: Spectrum Books.

List of Vice Presidents of Nigeria (http://en.wikipedia.org/wiki vice_president_of_Nigeria) 15 September 2008.

Mu’azzam, I.\& Ibrahim, J., 2003, 'Religious Identity in the Context of Structural Adjustment in Nigeria’, in A. Jega, ed., Identity Formation and Identity Politics Under Structural Adjustment in Nigeria. Kano/Uppsala: Centre for Research and Documentation and Nordiska Africainstitutet.

Nabudere, D.W., 2000, 'Globalization, the African Post-Colonial State, Post Traditionalism, and the New World Order', in D.W.Nabudere, ed., Globalization and The Post- Colonial African State, Harare: Zimbabwe AAPS Books.

Nnoli, O., 1981, 'A Short History of Nigerian Development', in O.Nnoli ed., Path to Nigerian Development, Dakar:.CODESRIA.

Nnoli, O., 1989, Ethnic Politics in Africa, Nigeria, African Association of Political Science.

Obianyo, N.E., 2001, 'The Political Economy of Sectionalismè in Anambra State', in Nnamdi Azikiwe Journal of Political Science, Vol. 2, No.1.

Obianyo, N.E., 2008, 'Citizenship and Ethnic Militia Politics in Nigeria: Marginalization or Identity Question? -The Case of MASSOB', Paper presented at the $4^{\text {th }}$ Global Conference on Pluralism Inclusion and Citizenship, Salzburg, 31 October,- 4 November 2008.

Offiong, D.A., 2001, Globalization and Post Neo Dependency in Africa, Enugu; Fourth Dimensions.

Osaghae, E., 2003, 'Colonialism and Civil Society in Africa:The perspective of Eke’s Two Publics', Paper presented at the symposium on Canonical Works and Continuing Innovation in African Arts and Humanities, Accra, Ghana. 17-19 September Available Online (http:/www.codesria.org/links/conferences/ accra/osaghae.pdf). 22 September 2008.

Unizik Comet, 2003, ‘Current Appointment in Unizik’ , Awka Mass Communication Department.

Zeleza, P.T. (n.d), 'Imaging and Inventing the Post Colonial State in Africa', in Contours (http://www.press.uillinois.edu/journals/contours/1.1/zeleza.html). 11 November 2006. 